violet to green, so that the green of the narrower bow lay next to the violet of the primary bow ; the other lay immediatoly outside the secondary bow and had colours in the same order as the primary bow and its companion. The prirnary bow was visible for longer than the other three. Some, at least, of the rain which gave rise to the four bows was associated with a distant thunderstorm. An explanation must presumably be sought in a probable grouping of the raindrops into at least two principal sizes, the larger drops being no doubt produced in the thunderstorm, for it is known that drops of different sizes produce bows of different coloration and width. The fact that the two outer bows had their colours arranged in opposite order, however, seems difficult to reconcilo with this suggestion. Accounts from other observers would be of interest.

\section{Sea-Waves of the Japanese Earthquake of March 2, 1933}

THE great earthquake of March 2, that originated near the western edge of the Tuscaroora Deep, was registered by seismographs at the three Hawaiian observatories of Kilauea, Kona and Hilo (Volcano Letter, Hawaiian Volcano Observatory, No. 397, March, 1933). As the seismograms showed that the distance of the origin was about 3,950 miles in the direction of Japan, it was clear that the movernent might be followed in about $8 \frac{1}{2}$ hours by seismic seawaves. Notice was sent to the harbour-masters in the islands that waves might be expected at about 3.30 p.m. (Hawaiian time), and in consequence the fishing-boats were moved out to sea and many of them were no doubt saved by theso timely precautions. The waves entered Hilo, on the east side of Hawaii, at 3.36 p.m., and continued to sweep in for about two hours, the greatest range of motion being 2-3 ft. On the west side of Hawaii, the sca-level with the greatest wavo fell $8 \mathrm{ft}$. and rose $9 \frac{1}{2} \mathrm{ft}$.; walls were washed away and boats left in the ports were unmoored and capsized. At Honolulu, the first waves arrived at 2.40 p.m. or about $7 \mathrm{~h} .40 \mathrm{~m}$. after the earthquake occurred in Japan. In 1896, the interval was $7 \mathrm{~h} .44 \mathrm{~m}$., and thus it may be inferred that the foci of the two earthquakes were not far apart.

\section{Photoelectric Cell Applications at the Science Museum}

THE special exhibition of photoelectric cells and their practical applications, which has been on view at the Science Museum since March, has proved of such interest both to specialists and to the general public that it has been decided to extend it up to the ond of September. Almost without oxception the firms and individuals who originally lent apparatus for inclusion in the exhibition have kindly consented to continue the loan for the further period. While the essential features of the exhibition will thus remain unchanged, several interesting additions have recently been made. Prominent among these is a 'chart analyser', lent by the Post Office Enginecring Research Station, which analyses records of the alternating periods of 'use' and of 'idleness' of certain pieces of apparatus employed in automatic telophony. These records are passed beneath a photoelectric cell connected to amplifying apparatus which records upon two dials the desired information--the total duration of the periods of 'use' and their number. A further exhibit has boon prepared to illustrated the application of photoelectric cells in the transmission of pictures, telegrams, etc., by line or radio telegraphy; some early apparatus used for this purpose and some of the first pictures actually transmitted are shown. Among new instruments added since the exhibition was opened are a direct-reading portable illumination meter and the 'blancometer', which measures accurately tho departure from a standard whiteness of a nearly-white surface.

\section{Long Steel Castings for Cotton Presses}

In discussing the first report of the Steel Castings Research Committee of the Iron and Steel Institute recently, Sir Robert Hadfield referred to some hydraulic cylinders made by Messrs. Hadfields, Ltd. for cotton presses. These cylinders, which had an overall length of nearly $27 \mathrm{ft}$., required the production, including the feeder head, of castings some $32 \mathrm{ft}$. long. They were cast vertically at a temperature of about $1,530^{\circ} \mathrm{C}$. and contracted in solidification and subsequent cooling by about 8 in. To permit of this considerable change in length, the clamped moulding box must be removed almost immediately after the steol has set. Since those castings are tested hydraulically at pressures in some cases up to 4 tons por sq. in., and since the working pressure amounts to $2 \frac{1}{2}$ tons per sq. in., it is clearly nocessary that they should be completely free from the least suspicion of unsoundness of any sort. Their outside diameter was 15 in. and wall thickness only $2 \frac{1}{8}$ in. Their production represents a noteworthy achievement. A drawing showing the casting process was exhibited at the Royal Society soirées on June 21 .

\section{The State and Economic Life}

A PAMPhLet entitled "The State and Fconomic Life" recently issued by the International Institute of Intellectual Co-operation, summarises opinions reached during the Sixth International Studies Conference. Among the more important matters discussed was that of international capital movements. It is pointed out in the report, that since the War there has been unwise and excessive lending abroad, which is partly responsible for the present position. The general economic disequilibrium created an abnormal demand for foreign credit and this was intensified by the huge amounts of intergovernmental indebtedness. Foreign loans were often obtained to cover budgetary deficits, to stabilise temporarily balances of payments or for unjustifiably extravagant purposes. Such borrowing, though it may have delayed the international collapse, has certainly contributed to the gravity of the crisis. Furthermore, unstable conditions increased speculative facilities and abnormal interest rates gave rise to an unprecedented volume of international short-term lending. To-day the almost complete cessation of international financial trans- 